\title{
KANDUNGAN GIZI, RENDEMEN TEPUNG, DAN KADAR FENOL TOTAL ALPUKAT (Persea americana, Mill) VARIETAS IJO PANJANG DAN IJO BUNDAR
}

\author{
Nutrients Content, Dried Pulp Rendement, and Total Phenolic Content of Avocado (Persea americana, Mill) \\ Variety of ljo Panjang and ljo Bundar
}

Wuri Marsigit ${ }^{1}$, Mary Astuti ${ }^{2}$, Sri Anggrahini' ${ }^{2}$, Sri Naruki ${ }^{2}$

${ }^{1}$ Jurusan Teknologi Pertanian, Fakultas Pertanian, Universitas Bengkulu, Jl. WR Supratman, Bengkulu 38371

${ }^{2}$ Jurusan Teknologi Pangan dan Hasil Pertanian, Fakultas Teknologi Pertanian, Universitas Gadjah Mada, Jl. FloraNo. 1, Bulaksumur, Yogyakarta 55281

Email: wuri_marsigit@yahoo.com

\begin{abstract}
ABSTRAK
Penelitian ini bertujuan untuk mengetahui proporsi daging buah, rendemen tepung, kandungan gizi dan fenol total alpukat varietas Ijo Panjang dan Ijo Bundar. Pemilihan kedua varietas tersebut karena merupakan varietas unggul dan direkomendasikan untuk dikembangkan di Indonesia. Kandungan, air, karbohidat, protein, lemak dan abu dilakukan dengan analisis proksimat (AOAC), kandungan vitamin A dan $\mathrm{E}$ dengan metode spektrofotometri dan vitamin $\mathrm{C}$ dengan metode titrasi, analisis mineral dengan metode AAS. Total fenol dianalisis dengan metode Folin-Ciocalteu. Hasil penelitian menunjukan bahwa proporsi daging buah, kadar air, seng varietas Ijo Panjang lebih tinggi dibandingkan Ijo Bundar. Rendemen tepung alpukat lebih tinggi pada varietas Ijo Bundar. Kandungan protein, lemak, abu, vitamin (A,E dan $\mathrm{C}$ ), mineral (Fe, Na, K, P) lebih tinggi pada varietas Ijo Bundar. Kandungan magnesium dan mangan tidak terdapat perbedaan signifikan kedua varietas. Fenol total daging buah dan tepung alpukat lebih tinggi pada varietas Ijo Bundar dibandingkan Ijo Panjang.
\end{abstract}

Kata kunci: Prorporsi daging buah, rendemen tepung, kandungan gizi, fenol total

\begin{abstract}
The aims of the study were to determine pulp proportion, dried pulp rendement, nutrient dan total phenolic content avocado variety of Ijo Panjang dan Ijo Bundar. Variety of Ijo Panjang and Ijo Bundar were selected because both of varieties were categorized as excelent varities and recomendedto develop in Indonesia. Water, carbohydrate, protein, fat dan ash content were determined by using proxymate analysis (AOAC), vitamin A dan E using spectrophotometry method, vitamin $\mathrm{C}$ using titration method, dan minerals using AAS method. Total phenolic content were determined by using Follin-Cialcetau method. The result of the studies found that pulp portion Ijo Bundar Variety higher than Ijo Panjang. Water content dan zinc of Ijo Panjang variety higher than Ijo Bundar. Dried pulp rendement of Ijo Bundar higher than Ijo Panjang. Protein, fat, ash, minerals ( Fe, Na, K dan P) avocado variety of Ijo Bundar higher than Ijo Panjang. Magnesium dan mangan content of both varieties have not significant different. Total phenolic content of pulp dan dried pulp were higher in Ijo Bundar than Ijo Bundar.
\end{abstract}

Keywords: Pulp proportion, dried pulp rendement, nutrients dan total phenolics content

\section{PENDAHULUAN}

Alpukat (Persea americana, Mill) merupakan salah satu buah lokal yang banyak dikembangkan di Indonesia. Produksi alpukat cenderung meningkat dari tahun ke tahun, yaitu 224.278 ton pada tahun 2010, 275.953 ton pada tahun 2011 dan 290.810 ton pada tahun 2012 (Anonim,
2012). Peningkatan produksi tidak diikuti oleh tingkat konsumsi,dimana konsumsi alpukat masih sangat rendah yaitu rata-rata hanya sekitar 472 gram per kapita per tahun (Anonim, 2012). Rendahnya konsumsi kemungkinan disebabkan ketidaktahuan mengenai manfaat alpukat bagi kesehatan, atau persepsi yang keliru sebagian kalangan selama ini, menganggap bahwa alpukat tidak menguntungkan 
dari aspek kesehatan karena mengandung lemak tinggi yang dapat meningkatkan kadar kolesterol darah, sehingga membahayakan bagi kesehatan (Haryanti, 2012).

Terdapat beberapa varietas alpukat yang dapat tumbuh di Indonesia, baik yang unggul dan tidak unggul (Rismunamdar, 1981; Kalie, 1997; Indriyani dan Suminarsih, 1997). Varietas yang tidak unggul tidak direkomendasikan untuk dikembangkan tetapi hanya merupakan plasma nutfah, meliputi varietas Merah Panjang, Merah Bundar, Dickson, Butler, Winslowson, Benik, Puebla, Fuerte, Collinson, Waldin, Ganter, Mexcola, Duke, Ryan, Leucadia, Queen dan Edranol, serta terdapat pula varietas unggul yang direkomendasikan untuk dikembangkan (Anonim, 2000). Menteri Pertanian RI pada tanggal 14 Januari 1987 telah menetapkan 2 varietas unggul, yaitu alpukat Ijo Panjang dan Ijo Bundar. Dalam penelitian ini dipilih varietas Ijo Panjang dan Ijo Bundar karena merupakan varietas unggul dan direkomendasikan sebagai varietas untuk dikembangkan di Indonesia. Sifat-sifat kedua varietas tersebut antara lain tinggi pohon alpukat Ijo Panjang 5-8 m, Ijo Bundar 6-8 m. Bentuk daun Ijo Panjang bulat panjang dengan tepi rata, Ijo Bundar bulat panjang dengan tepi berombak. Berat buahIjo Panjang 0,3-0,5 kg, Ijo Bundar 0,3-0,4 kg. Bentuk buah alpukat Ijo Panjang bentuk pear (pyriform), alpukat Ijo Bundar lonjong (oblong). Rasa buah alpukat Ijo Panjang enak, gurih, agak lunak/basah, Ijo Bundar enak, gurih, agak kering. Diameter buah alpukat Ijo Panjang 6,5-10 cm, alpukat Ijo Bundar 7,5 cm.Panjang buah: alpukat Ijo Panjang 11,5-18 cm (rata-rata $14 \mathrm{~cm}$ ), alpukat Ijo Bundar $9 \mathrm{~cm}$. Hasil panen alpukat Ijo Panjang 40-80 kg/ pohon/tahun (rata-rata $50 \mathrm{~kg}$ ), alpukat Ijo Bundar 20-60 kg/ pohon/tahun (rata-rata $30 \mathrm{~kg}$ ). Perbedaan visual bentuk buah dan daun alpukat varietas Ijo Panjang dan Ijo Bundar dapat dilihat pada Gambar 1 dan 2.

Belum banyak penelitian yang mengungkap potensi daging buah alpukat unggul Indonesia (varietas Ijo Panjang dan Ijo Bundar), khususnya dalam hal proporsi daging buah, kandungan gizi, rendemen tepung, total fenol dan bahan-bahan aktif lain yang terkandung pada kedua varietas tersebut. Penelitian tersebut penting untuk melihat manfaat daging buah alpukat dari aspek gizi dan kesehatan, serta kemungkinan pemanfaatan tepung alpukat sebagai pangan fungsional (makanan olahan maupun food supplement). Dengan penelitian ini diharapkan dapat terungkap potensi yang terdapat pada dua varietas buah alpukat baik dalam bentuk buah segar maupun tepung alpukat untuk dipromosikan sebagai buah lokal yang sehat sehingga dapat meningkatkan derajat kesehatan masyarakat. Dengan terungkapnya potensi kedua varietas tersebut akan dipilih satu varietas yang lebih baik untuk dilakukan penelitian lebih lanjut.

Penelitian ini bertujuan untuk mengetahui perbedaan proporsi daging buah, kandungan gizi, rendemen tepung, dan

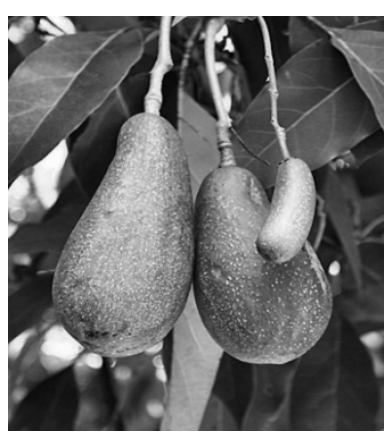

Gambar 1. Varietas Ijo Panjang

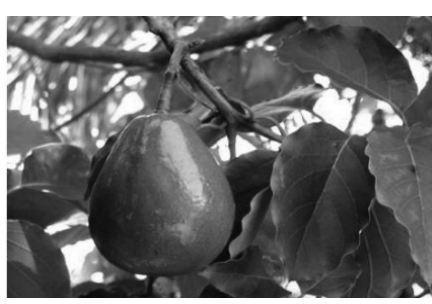

Gambar 2. Varietas Ijo Bundar kandungan total fenol antara alpukat varietas Ijo Panjang dan Ijo Bundar.

\section{METODE PENELITIAN}

Bahan utama alpukat dua viarietas yaitu Ijo Panjang dan Ijo Bundar diambil dari petani di Sentolo dan Bandungan pada kondisi masih mengkal (matang fisiologis) yaitu sekitar 6-7 bulan setelah berbunga, kemudian ditunggu sampai matang sebagaimana yang biasa dikonsumsi oleh masyarakat pada umumnya.

Bahan kimia utama yang digunakan dalam penelitian ini antara lain aseton p.a, etanol p.a., metanol p.a., natrium bisulfit, follin-cialcetau, akuades, asam gallat sodium carbonat.

Peralatan yang digunakan antara lain timbangan (mettler toledo), oven (memmert 854 schabach), cabinet dryer, tanur pengabuan (lenton furnace), blender (philips), ayakan (RetschMesh 60), rotary evaporator (IKA RV-10 Basic), spektrofotometer (UV-Vis Shimadzu 1601), AAS (Perkin Elmer 3100), freeze dryer (Eyella), vortex (Velp Scientifica) shaker (Julaba SW22), waterbath (Achtung), peralatan gelas dan peralatan penunjang lainnya (gelas ukur, soxhlet, micro Kjehdahl, kertas saring, corong, erlen meyer, alat titrasi dan tabung reaksi).

\section{Pengambilan Sampel}

Sebanyak 3 sampel masing varietas dengan berbagai ukuran buah digunakan dalam penelitian ini. Masing-masing sampel tiap varietas mewakali ukuran besar yaitu dengan berat 451-550 g/buah, sedang 351-450 g/buah dan kecil 250-350 g/buah (Anonim, 1992; Indriyani dan Suminarsih, 1997). Masing ukuran diwakili 1 buah sehingga tiap varietas terdiri dari 3 sampel. Buah tersebut diambil dalam keadaan mengkal dibiarkan matang dalam kotak kardus yang diberi serpihan potongan kertas selama lebih kurang 6 hari. Setelah matang dipisahkan dari biji dan kulit, dan dilumatkan, sehingga diperoleh daging buah yang menyatu antara bagian atas tengah dan bawa buah untuk tiap varietas dan tiap 
ukuran buah. Selanjutnya dilakukan pengukuran proporsi daging buah, rendemen tepung alpukat, analisis proksimat, kandungan vitamin, mineral dan total fenol.

\section{Penentuan Proporsi Daging Buah}

Untuk megetahui proporsi daging buah tehadap berat buah total buah, dilakukan penimbangan berat daging buah, berat biji, berat kulit, dan berat buah keseluruhan. Proporsi daging buah merupakan perbandingan antara berat daging buah dengan berat buah secara keseluruhan dikalikan $100 \%$.

\section{Preparasi Tepung Alpukat}

Alpukat matang dipisahkan daging buah dari kulit dan biji pada prosedur pengukuran proporsi daging buah. Selanjutnya diiris melintang dengan ketebalan 2-3 mm, direndam dalam natrium meta bisulfit 1000 ppm selama lebih kurang lebih 15 menit, ditiriskan dan dikeringkan dengan cabinet dryer pada suhu $\pm 60^{\circ} \mathrm{C}$. Daging buah alpukat yang sudah kering kemudian digiling/dihancurkan dengan penggiling, hasil gilingan diayak menggunakan pengayak 60 mesh, sehingga diperoleh tepung alpukat yang halus (Moljaningsih, 2008). Rendemen tepung alpukat dihitung berdasarkan berat tepung yang diperoleh dibagi dengan berat daging alpukat segar dikalikan 100\%.

\section{Analisis Kandungan Gizi}

Analisis kandungan senyawa kimia pada alpukat meliputi analisis proksimat pada daging buah segar dan tepung alpukat. Analisis kimia yang dilakukan adalah analisis kadar air, kadar protein, kadar lemak, kadar abu, serat kasar dan kadar karbohidrat by defference (AOAC, 2005). Kadar karbohidrat by different dihitung dengan menggunakan rumus: kadar bohidrat $(\%)=100 \%-(\%$ air $+\%$ abu $+\%$ protein $+\%$ lemak). Analisis kandungan vitamin A, E dan C dilakukan di Pusat Studi Pangan dan Gizi UGM menggunakan spektrofotometer dan titrasi, sedangkan analisis kandungan mineral di Laboratorium Kimia Analitik, FMIPA UGM menggunakan AAS.

\section{Ekstraksi Fenol Daging Buah dan Tepung Alpukat}

Sebanyak 10 g contoh ditambahkan $100 \mathrm{ml}$ air 100\%, aseton 70\% (70\% aseton dicampur dengan $30 \%$ air, v/v) dan etanol 70\% (70\% etanol dicampur dengan 30\% air, $\mathrm{v} / \mathrm{v}$ ) diaduk dengan shaker suhu $25^{\circ} \mathrm{C}$, selama semalam (overnight), selanjutnya disaring menggunakan kertas saring WhatmanNo 1. Residu yang diperoleh diekstrak kembali dengan prosedur yang sama selama 3 jam sebanyak 3 kali. Supernatan yang dihasilkan disatukan dan dievaporasi dengan rotary evaporator pada suhu $40{ }^{\circ} \mathrm{C}, 70 \mathrm{rpm}$ untuk menghilangkan pelarut organik (aseton dan etanol), untuk menghilangkan air dilakukan dengan pengeringan beku (Becker dan Sindddhuraju, 2006; Sultana dkk., 2007).

\section{Pengkuran Fenol Total dengan Spektrofotometer (Rodriguez-Carpenadkk., 2011)}

Ekstrak contoh sebanyak $\pm 0,2 \mathrm{ml}(0,5 \mathrm{~g}$ ekstrak kering dalam $5 \mathrm{ml}$ pelarut metanol) ditambahkan $1 \mathrm{ml}$ Folin-Ciocalteu (pengenceran 1:10). Kemudian tambahkan $0,8 \mathrm{ml}$ sodium carbonat 7,5\% (w/v), divortex. Biarkan di ruang gelap selama 30 menit dan diukur absorbansinya pada panjang gelombang $725 \mathrm{~nm}$ (Rodriguez-Carpena dkk., 2011). Kurva standar dibuat menggunakan asam galat (gallic acid equivalent) dengan konsentrasi $0 ; 0,02 ; 0,04 ; 0,06 ; 0.08$ dan $0,1 \mathrm{mg} / \mathrm{ml}$ atau 0, 20, 40,60, 80 dan $100 \mathrm{ppm}$. Dari pengujian kurva standar diperoleh persamaan $\mathrm{Y}=7,202 \mathrm{X}-0,035$ dengan $\mathrm{R}^{2}=0,992$.

\section{Analisis Statistik}

Data yang diperoleh merupakan rata-rata (mean) dan standar deviasi (SD) dari tiga sampel dari masing-masing verietas yang mewakli ukuran besar, sedang dan kecil. Jadi tiap varietas terdiri dari tiga sampel. Untuk melihat perbedaan pengamatan kedua varietas tersebut dilakukan uji T-Test.

\section{HASIL DAN PEMBAHASAN}

\section{Proporsi Daging Buah}

Dilihat dari proporsi daging buah (pulp), alpukat varietas Ijo Panjang (73.11 \%) lebih tinggi dibandingkan dengan varietas Ijo Bundar $(71.24 \%)(p<0.05)$, proporsi biji lebih tinggi pada varietas Ijo Bundar $(\mathrm{p}<0.01)$, sedangkan proporsi kulit lebih tinggi pada varietas Ijo Panjang $(\mathrm{p}<0.01)$ (Tabel 1). Proporsi daging buah biasanya merupakan bagian yang dapat dimakan (Anonim, 1992). Dari data tersebut terlihat bahwa varietas merupakan faktor yang menentukan proporsi daging buah. Proporsi daging buah, biji dan kulit alpukat, disamping ditentukan oleh varietas, juga ditentukan oleh cara budidaya, kondisi tumbuh, faktor-faktor lingkungan (Rodriguez-Carpena dkk., 2011; Mooz dkk., 2012; Qing Li dkk., 2009). Varietas Ijo Panjang merupakan jenis alpukat yang berbiji kecil, berkulit tebal, sedangkan Ijo Bundar berkulit tipis dan berbiji besar (Anonim, 2000). Sebagai perbandingan, Rodriguez-Carpena dkk. (2011) meneliti dua varietas alpukat Fuerte dan Hass mendapatkan bahwa proporsi daging buah varietas Fuerte $75,85 \%$, sedangkan varietas Hass proporsi daging buah 68,75\%. Avilan dkk. (1994) mendapatkan bahwa proporsi daging buah varietas Fuerte adalah 83\% sedangkan Hass 72,19\%. 
Tabel 1. Proporsi bagian buah

\begin{tabular}{lccc}
\hline \multirow{2}{*}{ Bagian buah } & \multicolumn{2}{c}{ Proporsi bobot $(\%)$} & \multirow{2}{*}{ Nilai $\mathrm{p}$} \\
\cline { 2 - 3 } & Ijo Panjang & Ijo Bundar & \\
\hline Daging buah & $73,16 \pm 0,28$ & $71,24 \pm 0,11$ & $\mathrm{p}<0,05$ \\
Biji & $15,02 \pm 0,08$ & $20,22 \pm 0,26$ & $\mathrm{p}<0,01$ \\
Kulit & $11,82 \pm 0,32$ & $8,54 \pm 0,15$ & $\mathrm{p}<0,01$ \\
\hline
\end{tabular}

\section{Rendemen Tepung Alpukat}

Rendemen tepung daging buah alpukat lebih tinggi pada varietas Ijo Bundar (23,29\%) dibandingkan varietas Ijo Panjang $(20,67 \%)(p<0,05)$. Perbandingan rendemen kedua varietas dapat dilihat pada Tabel 2. Hal ini kemungkinan disebabkan oleh kandungan air yang tinggi pada varietas Ijo Panjang, namun kandungan padatannya lebih rendah, sedangkan pada varietas Ijo Bundar. Bentuk buah alpukat Ijo Panjang bentuk pear (pyriform), alpukat Ijo Bundar lonjong (oblong). Rasa buah alpukat Ijo Panjang enak, gurih, agak lunak/basah, Ijo Bundar enak, gurih, agak kering (Anonim, 2000). Alpukat yang berbentuk pyriform cenderung memiliki kadar air yang lebih tinggi dibandingkan berbentuk lonjong (oblong) (Rodriguez-carpena dkk., 2011; Schwartz dkk., 2007). Kualitas daging buah alpukat disamping ditentukan oleh varietas, juga ditentukan oleh kondisi tumbuh, faktorfaktor lingkungan, tingkat kematangan, dan penanganan pasca panen buah (Rodriguez-Carpena dkk., 2011; Avilan dkk., 1994). Perbedaan visual tepung alpukat Ijo Panjang dan Ijo Bundar dapat dilihat pada Gambar 3 dan 4.

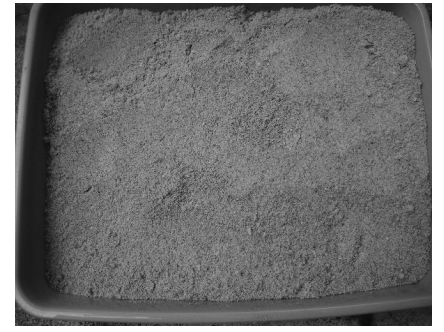

Gambar 3. Tepung alpukat Ijo Gambar 4. Tepung alpukat Ijo Panjang

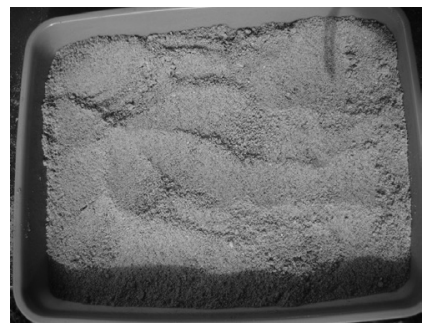

Bundar
Tabel 2. Rendemen tepung alpukat

\begin{tabular}{lccc}
\hline Bobot & Ijo Panjang & Ijo Bundar & Nilai p \\
\hline Daging buah alpukat (g) & $400,41 \pm 0,19$ & $400,31 \pm 0,24$ & \\
Tepung alpukat (g) & $82,78 \pm 1,83$ & $93,26 \pm 2,66$ & \\
Rendemen (\%) & $20,67 \pm 0,45$ & $23,29 \pm 0,66$ & $\mathrm{p}<0,05$ \\
\hline
\end{tabular}

\section{Kandungan Gizi Daging Buah Alpukat Segar dan Tepung Alpukat}

Alpukat mengandung karbohidrat, lemak, protein, serat, vitamin, dan mineral (Arukwe dkk., 2012; Mooz dkk., 2012; Mefba dkk., 2008; Moelyaningsih, 2008; Qing-Yi, 2009). Alpukat mengandung karotenoid (lutein, zeaxantin, $\alpha$-karoten, $\beta$-karoten) dan tokoferol (alfa-tokoferol, betatokoferol dan tokotrienol) dan vitamin C (Arpaian dkk., 2006; Qing-Yi, 2009). Alpukat juga merupakan sumber mineral sepert seng, besi, natrium, kalium, fosfor,kalsium, mangan dan magnesium (Arukwe dkk., 2012; Orchevba dan Jinadu, 2011; Anonim, 1992).

Analisis proksimat menunjukkan bahwa kadar air varietas Ijo Panjang $(81,81 \mathrm{~g} / 100 \mathrm{~g})$ lebih tinggi dibandingkan varietas Ijo Bundar $(80,12 \mathrm{~g} / 100 \mathrm{~g})(\mathrm{p}<0,05)$, namun kandungan protein lemak dan abu lebih tinggi pada varietas Ijo Bundar yaitu 1,77 ( $\mathrm{p}<0,05), 7,81(\mathrm{p}<0,05)$ dan 0,77 $\mathrm{g} / 100 \mathrm{~g}(\mathrm{p}<0,01)$ dibandingkan Ijo Panjang (Tabel 3). Jika dibandingkan dengan penelitian Rodriguez-Carperna dkk. (2011) yang mendapatkan bahwa kandungan air daging buah alpukat varietas fuerte yaitu 80,25\% varietas Hass $(77,38 \%)$, maka kadar air varietas Ijo Panjang dan Ijo Bundar melebihi varietas fuerte dan Hass. Sedangkan lemak, protein dan abu lebih rendah dibawah varietas Hass $(15,8,1,80$ dan 1,01 g/100 g) dan Fuerte (12,50, 1,2 dan 1,45 g/100 g). Penelitian Moeljaningsih (2008), mendapatkan kandungan air 80,3 g/100 $\mathrm{g}$, lemak 7,6 \%, protein $0,5 \mathrm{~g} / 100 \mathrm{~g}$ dan abu $1,13 \mathrm{~g} / 100 \mathrm{~g}$.

Tabel 3. Kandungan gizi daging buah alpukat

\begin{tabular}{lccc}
\hline \multirow{2}{*}{ Komponen gizi } & \multicolumn{2}{c}{ Kandungan $(\mathrm{g} / 100 \mathrm{~g})$} & \multirow{2}{*}{ Nilai $\mathrm{p}$} \\
\cline { 2 - 3 } & Ijo Panjang & Ijo Bundar & \\
\hline Air & $81,81 \pm 0,79$ & $80,12 \pm 0,61$ & $\mathrm{p}<0,05$ \\
Karbohidrat & $8,84 \pm 0,89$ & $9,98 \pm 0,51$ & \\
Protein & $1,32 \pm 0,09$ & $1,77 \pm 0,05$ & $\mathrm{p}<0,05$ \\
Lemak & $7,13 \pm 0.88$ & $7,81 \pm 0,13$ & $\mathrm{p}<0,05$ \\
Abu & $0,44 \pm 0,01$ & $0,77 \pm 0,01$ & $\mathrm{p}<0,01$ \\
\hline
\end{tabular}

Sama halnya dengan daging buah alpukat, kandungan air varietas Ijo Panjang pada tepung alpukat lebih tinggi dibandingkan varietas Ijo Bundar, namun untuk kandungan protein $(\mathrm{p}<0,05)$, lemak $(\mathrm{p}<0,01)$ dan abu $(\mathrm{p}<0,05)$ lebih tinggi pada varietas Ijo Bundar (Tabel 4). Penelitian sebelumnya, yang dilakukan Moeljoningsih (2008) yang menggunakan varietas Persea gratisssima mendapatkan kandungan karbohidirat $(60,42 \mathrm{~g} / 100 \mathrm{~g})$, air $(13,65 \mathrm{~g} / 100$ $\mathrm{g})$, sedangkan untuk kadar protein $(0,28 \mathrm{~g} / 100 \mathrm{~g})$, lemak $(20,35 \mathrm{~g} / 100 \mathrm{~g})$ dan abu $(0,42 \mathrm{~g} / 100 \mathrm{~g})$. 
Tabel 4. Kandungan gizi tepung alpukat

\begin{tabular}{lccc}
\hline \multirow{2}{*}{ Komponen gizi } & \multicolumn{2}{c}{ Kandungan $(\mathrm{g} / 100 \mathrm{~g})$} & \multirow{2}{*}{ Nilai $p$} \\
\cline { 2 - 3 } & Ijo Panjang & Ijo Bundar & \\
\hline Air & $11,3 \pm 0,24$ & $10,14 \pm 0,08$ & $\mathrm{p}<0,05$ \\
Karbohidrat & $59,37 \pm 0,1$ & $59,95 \pm 0,09$ & \\
Protein & $0,32 \pm 0,02$ & $0,36 \pm 0,02$ & $\mathrm{p}<0,05$ \\
Lemak & $25,12 \pm 0,27$ & $25,69 \pm 0,05$ & $\mathrm{p}<0,01$ \\
Abu & $3,87 \pm 0,01$ & $4,07 \pm 0,09$ & $\mathrm{p}<0,05$ \\
\hline
\end{tabular}

Kandungan vitamin A $(\mathrm{p}<0,01)$, E $(\mathrm{p}<0,01)$ dan C $(\mathrm{p}<0,01)$ daging buah alpukat varietas Ijo Bundar lebih tinggi dibandingkan dengan varietas Ijo Panjang (Tabel 5). Kandungan vitamin A dan E baik varietas Ijo Panjang maupun Ijo Bundar masih lebih tinggi dibandingkan varietas Hass, dimana kandungan vitamin A $365 \mu \mathrm{g} / 100 \mathrm{~g}$, vitamin E 3,1 mg/100g (Qing-Yi dkk., 2009). Demikian pula halnya dengan vitamin $\mathrm{C}$ lebih tinggi dibandingkan varietas Fuerte yang hanya $15 \mathrm{mg} / 100 \mathrm{~g}$ (Arpaian dkk., 2006).

Tabel 5. Kandungan vitamin daging buah alpukat

\begin{tabular}{lccc}
\hline Kadar $(\mathrm{mg} / 100 \mathrm{~g})$ & Ijo Panjang & Ijo Bundar & Nilai $\mathrm{p}$ \\
\hline Vitamin A $(\mu \mathrm{g} / 100 \mathrm{~g})$ & $832,39 \pm 2,55$ & $4121,56 \pm 25,9$ & $\mathrm{p}<0,01$ \\
Vitamin E $(\mathrm{mg} / 100 \mathrm{~g})$ & $40,24 \pm 0,97$ & $79,45 \pm 0,17$ & $\mathrm{p}<0,01$ \\
Vitamin C $(\mathrm{mg} / 100 \mathrm{~g})$ & $49,69 \pm 0,79$ & $71,02 \pm 1,73$ & $\mathrm{p}<0,01$ \\
\hline
\end{tabular}

Seperti halnya pada daging buah alpukat, kandungan vitamin A $(p<0,01), E(p<0,01)$ dan $C(p<0,01)$ tepung alpukat lebih tinggi varietas Ijo Bundar dibandingkan varietas Ijo Panjang (Tabel 6). Belum banyak penelitian yang berhubungan kandungan vitamin tepung alpukat, sehingga tidak bisa dibandingkan dengan temuan-temuan sebelumnya.

Tabel 6. Kandungan vitamin tepung alpukat

\begin{tabular}{lccc}
\hline Kandungan $(\mathrm{g} / 100 \mathrm{~g})$ & Ijo Panjang & Ijo Bundar & Nilai $\mathrm{p}$ \\
\hline Vitamin A $(\mu \mathrm{g} / 100 \mathrm{~g})$ & $2812,06 \pm 8,61$ & $8792,82 \pm 31,17$ & $\mathrm{p}<0,01$ \\
Vitamin E $(\mathrm{mg} / 100 \mathrm{~g})$ & $136,39 \pm 1,98$ & $268,65 \pm 0,64$ & $\mathrm{p}<0,01$ \\
Vitamin C $(\mathrm{mg} / 100 \mathrm{~g})$ & $167,8 \pm 2,70$ & $358,76 \pm 1,16$ & $\mathrm{p}<0,01$ \\
\hline
\end{tabular}

Kandungan mineral magnesium $(\mathrm{p}>0,05)$ dan mangan ( $p>0,05)$ daging buah alpukat tidak terdapat perbedaan pada varietas Ijo Panjang dan varietas Ijo Bundar, namun mineral lain seperti kalsium ( $\mathrm{p}<0,01)$, besi $(\mathrm{p}<0,01)$, natrium ( $\mathrm{p}$ $<0,05)$, kalium $(\mathrm{p}<0,01)$ dan fosfor $(\mathrm{p}<0,01)$ lebih tinggi pada varietas Ijo Bundar (Tabel 7). Dibandingkan dengan penelitian Arukwe dkk. (2012) yang menggunakan varietas Hass, kandungan natrium $(385,14 \mathrm{mg} / 100 \mathrm{~g})$ varietas lebih rendah, namun mineral lain seperti kalsium $(12,4 \mathrm{mg} / 100 \mathrm{~g})$, besi $(0,49 \mathrm{mg} / 100 \mathrm{~g})$, kalium $(385,14 \mathrm{mg} / 100 \mathrm{~g})$, magnesium
$(0,16 \mathrm{mg} / 100 \mathrm{~g})$, seng $(0,64 \mathrm{mg} / 100 \mathrm{~g}$ dan fosfor $(51 \mathrm{mg} / 100 \mathrm{~g})$ lebih tinggi pada varietas Ijo Panjang dan Ijo Bundar.

Tabel 7. Kandungan mineral daging buah alpukat

\begin{tabular}{lccc}
\hline Kandungan mineral & Ijo Panjang & Ijo Bundar & Nilai $\mathrm{p}$ \\
\hline Kalsium $(\mathrm{mg} / 100 \mathrm{~g})$ & $14,32 \pm 0,11$ & $16,13 \pm 0,02$ & $\mathrm{p}<0,01$ \\
Besi $(\mathrm{mg} / 100 \mathrm{~g})$ & $1,75 \pm 0,13$ & $1,94 \pm 0,03$ & $\mathrm{p}<0,01$ \\
Magnesium $(\mathrm{mg} / 100 \mathrm{~g})$ & $32,34 \pm 0,85$ & $31,83 \pm 0,57$ & $\mathrm{p}>0,05$ \\
Natrium $(\mathrm{mg} / 100 \mathrm{~g})$ & $10,73 \pm 0,23$ & $12,73 \pm 0,35$ & $\mathrm{p}<0,05$ \\
Kalium $(\mathrm{mg} / 100 \mathrm{~g})$ & $1587,45 \pm 35,87$ & $1804,08 \pm 36,45$ & $\mathrm{p}<0,01$ \\
Mangan $(\mathrm{mg} / 100 \mathrm{~g})$ & $0,27 \pm 0,04$ & $0,31 \pm 036,45$ & $\mathrm{p}>0,05$ \\
Seng $(\mathrm{mg} / 100 \mathrm{~g})$ & $3.25 \pm 0,14$ & $2,49 \pm 0,14$ & $\mathrm{p}<0,01$ \\
Fosfor $(\mathrm{mg} / 100 \mathrm{~g})$ & $271,73 \pm 5,02$ & $283,09 \pm 1,52$ & $\mathrm{p}<0,01$ \\
\hline
\end{tabular}

Seperti halnya pada daging buah alpukat, kandungan mineral tepung alpukat menunjukkan hasil yang konsisten, dimana kandungan mineral kalsium, besi, kalium, seng, fosfor $(\mathrm{p}<0,01)$ dan natrium $(\mathrm{p}<0,05)$ lebih tinggi pada varietas Ijo Bundar dibandingkan Ijo Panjang, kecuali magnesium dan mangan $(\mathrm{p}>0,05)$ yang tidak menunjukkan perbedaan yang nyata (Tabel 8). Kandungan mineral kalium, fosfor dan magnesium merupakan lebih tinggi dibandingkan mineralmineral lainnya. Belum banyak penelitian yang mengukur kandungan mineral pada tepung alpukat, sehingga belum bisa dibandingkan dengan temuan-temuan sebelumnya.

Tabel 8. Kandungan mineral tepung alpukat

\begin{tabular}{lccc}
\hline Kandungan mineral & Ijo Panjang & Ijo Bundar & Nilai $\mathrm{p}$ \\
\hline Kalsium $(\mathrm{mg} / 100 \mathrm{~g})$ & $56,48 \pm 0,28$ & $83,01 \pm 0,65$ & $\mathrm{p}<0,01$ \\
Besi $(\mathrm{mg} / 100 \mathrm{~g})$ & $7,62 \pm 0,122$ & $8,61 \pm 0,27$ & $\mathrm{p}<0,05$ \\
Magnesium $(\mathrm{mg} / 100 \mathrm{~g})$ & $122,68 \pm 0,24$ & $121,82 \pm 0,28$ & $\mathrm{p}>0,05$ \\
Natrium $(\mathrm{mg} / 100 \mathrm{~g})$ & $37,82 \pm 0.0,11$ & $44,89 \pm 1,23$ & $\mathrm{p}<0,01$ \\
Kalium $(\mathrm{mg} / 100 \mathrm{~g})$ & $2457,78 \pm 36,45$ & $2133,81 \pm 48,22$ & $\mathrm{p}<0,01$ \\
Mangan $(\mathrm{mg} / 100 \mathrm{~g})$ & $0,53 \pm 0,21$ & $0,48 \pm 0,07$ & $\mathrm{p}>0,05$ \\
Seng $(\mathrm{mg} / 100 \mathrm{~g})$ & $5,16 \pm 0,03$ & $2,39 \pm 0,03$ & $\mathrm{p}<0,01$ \\
Fosfor $(\mathrm{mg} / 100 \mathrm{~g})$ & $124,68 \pm 4,22$ & $126,98 \pm 3,99$ & $\mathrm{p}<0,05$ \\
\hline
\end{tabular}

\section{Kadar Fenol Total}

Alpukat kaya akan komponen bioaktif yang bermanfaat bagi kesehatan. Daging buah alpukat juga kaya akan polifenol (Arukwe dkk., 2012; Dai dan Muper, 2010; Qing-Li dkk., 2009; Rodriquez-Carpena dkk., 2011; Mooz, 2012; Xianli dkk., 2004). Kandungan polifenol daging alpukat lebih tinggi dibandingkan buah-buahan lainnya (Alothman dkk., 2009; Wang dkk., 2010; Ganhao dkk., 2004).

Kandungan fenol total baik daging buah alpukat (Tabel 9) maupun tepung alpukat (Tabel 10) menunjukkan kecenderungan yang sama bahwa kandungan fenol total 
varietas Ijo Bundar lebih tinggi dibandingkan Ijo Panjang baik pelarut etanol, air maupun aseton $(\mathrm{p}<0,05)$.

Rodriguez-Carpena dkk. (2011) mendapatkan bahwa kandungan fenolik total varietas Fuerte pelarut aseton dan etanol masing-masing 175 dan $145 \mathrm{mg}$ GAE /100 g sedangkan varietas Hass 100 dan 92 mg GAE/100 g. Dalam hal ini kandungan total fenol daging buah alpukat varietas Ijo Panjang dan Bundar lebih tinggi dibandingkan varietas Hass dan Fuerte, namun demikian varietas bukan hanya satu-satunya faktor yang menentukan kandungan total fenol alpukat. Beberapa penelitian mendapatkan bahwa komposisi kimia daging buah alpukat ditentukan oleh varietas, kondisi tumbuh, cara budidaya, faktor-faktor lingkungan, tingkat kematangan, perlakuan dan penanganan pasca panen, serta perlakuan pengolahan (Rodriguez-Carpena dkk., 2011; Mooz dkk., 2012; Qing Li dkk., 2009; Berassategi dkk., 2010; Arpaian dkk., 2006; Becker dan Siddhuraju, 2006; Ikpeme dkk., 2014).

Tabel 9. Kadar fenol total daging buah alpukat

\begin{tabular}{lccc}
\hline \multirow{2}{*}{ Pelarut } & \multicolumn{2}{c}{ Kadar total fenol (mg GAE/100 g) } & \multirow{2}{*}{ Nilai $\mathrm{p}$} \\
\cline { 2 - 3 } & Ijo Panjang & Ijo Bundar & \\
\hline Etanol & $106,91 \pm 1,52$ & $11,67 \pm 1,95$ & $\mathrm{p}<0,05$ \\
Air & $59,15 \pm 0.63$ & $62,71 \pm 1,12$ & $\mathrm{p}<0,05$ \\
Aseton & $184,13 \pm 1,59$ & $186,17 \pm 0,57$ & $\mathrm{p}<0,05$ \\
\hline
\end{tabular}

Fenol total yang terekstrak lebih tinggi pada tepung alpukat dibandingkan pada daging buah alpukat, hal ini didukung penelitian Ikpeme dkk. (2014) yang menggunakan pelarut etanol juga mendapatkan kecenderungan yang sama, yaitu untuk daging buah segar $297 \mathrm{mg}$ GAE/100 g dan untuk tepung alpukat $535 \mathrm{mg}$ GAE/100 g. Hal ini masih banyaknya komponen-komponen terikat air pada daging alpukat sehingga tidak dapat terlarut secara keseluruhan (Zou dan Yu, 2004). Berbeda dengan dengan tepung alpukat yang bentuknya sudah kering, sehingga air yang terikat pada bahan tidak banyak dibandingkan daging buah alpukat segar, baik menggunakan pelarut aseton, air maupun etanol (Chavan dkk., 2001). Perlakuan pengolahan suatu produk dapat mempengaruhi jumlah total fenol yang terekstraksi (Mooz dkk., 2012; Berassategi dkk., 2010; Arpaian dkk., 2006; Becker dan Siddhuraju, 2006; Ikpeme dkk., 2014). Fenol biasanya tersimpan dalam vacuola tanaman, dengan perlakuan pemecahan jaringan tanaman dan penggunaan pelarut yang sedikit polar seperti etanol dan aseton akan dapat mengekstraksi fenol lebih efektif (Chavan dkk., 2001; Zou dan Yu, 2004).
Tabel 10. Kadar fenol total tepung alpukat

\begin{tabular}{lccc}
\hline \multirow{2}{*}{ Pelarut } & \multicolumn{2}{l}{ Kadar total fenol (mg GAE/100 g) } & \multirow{2}{*}{ Nilai $\mathrm{p}$} \\
\cline { 2 - 3 } & Ijo Panjang & Ijo Bundar & \\
\hline Etanol & $197,31 \pm 0,57$ & $201,13 \pm 0,55$ & $\mathrm{p}<0,05$ \\
Air & $76,39 \pm 1,36$ & $80,07 \pm 1,19$ & $\mathrm{p}<0,05$ \\
Aseton & $220,48 \pm 5,27$ & $239,14 \pm 2,62$ & $\mathrm{p}<0,05$ \\
\hline
\end{tabular}

Pelarut seperti metanol, etanol, aseton, propanol, etil asetat dan dimetil formamida sering digunakan untuk mengekstraksi material pangan (Alothman dkk., 2009; Ganhao dkk., Turkmen dkk., 2006). Secara umum aseton dengan berbagai konsentrasi menghasilkan ekstrak yang paling efisien untuk tepung, biji-bijian dan buah-buahan (Wang dkk., 2010; Rodriguez-Carpena dkk., 2011; Turkmen dkk., 2006; Zou dan Yu, 2004). Penggunaan konsentrasi aseton $70 \%$ menunjukan hasil yang paling baik pada alpukat dibandingkan metanol, etanol dan etil asetat (Wang dkk., 2010; Rodriguez-Carpena dkk., 2011). Polaritas memegang peranan kunci dalam peningkatan kelarutan fenol, pelarut etanol dan aseton cocok untuk melarutkan fenol pada daging buah alpukat yang bersifat lipofilik (Alothman dkk., 2009; Rodriguez-Carpena dkk., 2011).

\section{KESIMPULAN}

Proporsi daging buah (pulp), kadar air daging buah alpukat dan tepung alpukat varietas Ijo Panjang lebih tinggi dibandingkan Ijo Bundar. Rendemen tepung alpukat lebih tinggi pada varietas Ijo Bundar, demikian pula halnya dengan kandungan protein, lemak, abu, vitamin (A, E dan $\mathrm{C}$ ), mineral (Fe, $\mathrm{Na}, \mathrm{K}, \mathrm{P}$ ), baik pada daging buah alpukat segar maupun tepung alpukat. Sedangkan kandungan magnesium dan mangan, daging alpukat segar dan tepung alpukat tidak terdapat perbedaan signifikan antara kedua varietas. Kandungan fenol total daging buah alpukat segar dan tepung alpukat lebih tinggi pada vaietas Ijo Bundar dibandingkan Ijo Panjang. Secara umum, berdasarkan kandungan protein, lemak, abu, vitamin (A,E dan C), mineral (Fe, Na, K, P), fenol total baik pada daging buah alpukat segar maupun tepung alpukat lebih baik pada varietas Ijo Bundar dibandingkan Ijo Panjang.

\section{DAFTAR PUSTAKA}

Anonim (2000). Alpukat/Avocad. Kantor Menristek Bidang Pendayagunaan dan Pemasyarakatan Ilmu pengetahuan dan Teknologi, Badan Pengkajian dan Penerapan Teknologi. Jakarta. 
Anonim (1992). Daftar Komposisi Bahan Makanan. Direktorat Gizi, Departemen Kesehatan RI. Bhratara Karya Aksara.

Anonim (2012). Konsumsi Sayuran dan Buah-buahan di Indonesia. Direktorat Jenderal Hortikultura, Departemen Pertanian.

Anonim (1992). Syarat Mutu Buah Alpukat Menurut SNI 013168-1992. Badan Standardisasi Nasional. Jakarta.

Anonim (2009). Tabel Komposisi Pangan Indonesia. Elex Media Komputindo, Kompas Gramedia.

Alothman, M., Bhat, R. dan Karin, A.A. (2009). Antioxidant capacity dan phenolic content of selected tropical fruits from Malaysia, extracted with different solvents. Food Chemistry 115: 785-788.

Arpaian, M., Jacman, C.R., White, A., Thomson, J.F. dan Slaughter, D.S. (2006). Avocado post harvest quality. Proceeding Avacado Research Simposium 2: 143-155.

Anonim (2005). Official Methods of Analysis of AOAC International. USA.

Arukwe, U., Amadi, B.A., Duru. M.K.C., Agomuo, F.M., Adindu, A., Odika, P.C., Lele, K.C., Egejuru, L. dan Anudike, J. (2012). Chemical composition of persea Americana leaf, fruit dan seed. International Journal of Research and Reviews in Applied Science 11: 346-349.

Avilan, R.L.A., Rodriguez, M.M. dan Dorantes I. (1994). Selection of avocado varieties. Agronomy Tropical44: 593-618.

Becker, K. dan Siddhuraju, P. (2006). Theantioxidant dan free radical scavenging activities of processed cowpea (Vigna unguiculata (L) Walp.) seed extracts. Food Chemistry 101: 10-19.

Berasategi, I., Barriuso., B., Ansorena, D. dan Astiasaran, I. (2010). Stability avocado oil during heating: comparative study to olive oil. Department of Nutrition, Food Science Physiology dan Toxicology. Faculty of Pharmacy. University of Navara, Irunlarrea Pamplona Spain.

Chavan, U.D., Sahidi, F. dan Naczk, M. (2001). Extraction of condensed tannin from beach pea (Lathyirus maritimus, L) as affected by different solvent. Food Chemistry 75 : 509-512.

Ganhao, R., Estevez, M., Killy, P. dan Morcuende, D. (2004). Characterization of selected wild mediteanian fruits dan vomparatives efficacy as inhibitor of oxydative reaction in emulsified raw fork burger. Journal of Agriculture and Food Chemistry 58: 8854-8862.
Garcia-Alonso, M., Pascual-Teressa, S. Santos-Buelga, C. dan Rivas-Gonzalo, J.C. (2004). Evaluation of the antioxidant properties of fruits. Food Chemistry 84: 13-18.

Haryanti, W.H. (2012). Potensi Omega-9 Asam Oleat pada Dading Buah Alpukat dalam Penurunan Kolesterol Serum Darah. Jurusan Pendidikan Biologi. Institut Keguruan dan Ilmu Pendidikan. Persatuan Guru Republik Indonesia, Semarang

Ikpeme, E.V., Ekaluo, U.B., Udensi O.U. dan Ekerette, E.E. (2014). Screening fresh and dried Fruits of avocado pear (Persea americana) for antioxidant activities: an alternative for syntetic antioxidant. Journal of Life Sciences Research and Discovery 1: 19-25.

Indriyani, Y.H. dan Suminarsih, E. (1997). Alpukat. Penebar Swadaya, Jakarta.

Kahkonen, M.P., Hopia, A.L., Vuorela, H.J., Rauha, J.P. dan Pihlaja, K. (1999). Antioxidant activity of plant extracts containing phenolics compound. Journal Agriculture and Food Chemistry 47: 3954-3962.

Kalie, M.B. (1997). Alpukat:Budidaya dan Pemanfaatannya. Kanisius, Yogyakarta.

Mefba, H.D., Sokari, T.G., Eboh, L., Banigo, E.B. dan KiinKabari (2008). Stabilized avocado pastes: chemical contents dan oxidative changes during storage. The Open Food Science Journal 2: 77-84.

Moeljaningsih (2008). Tepung alpukat sebagai campuran tepung terigu untuk pembuatan kue kering. Berita Litbang Industri XXXIX: 16-23.

Mooz, E.D., Gaino, N.M., Shimano, M.Y.H., Amancio, R.D. dan Spoto, M.H.F. (2012). Physical andchemical charecterization of pulp different varieties of avocado targeting oil extraction potencial. Cienecia Tecnologia de Alimentos, Campina 32(2): 274-280.

Orhevba, B.A. dan Jinadu, A.O. (2011). Determination of physico-chemical properties andnutritional of avocado pear (Persea Americana, Mill). Academic Research International 1(3): 29-38.

Qing-Yi, L., Zhang Y., Wang, Y., Wang, D., Lee, R.P., Gao, K., Byrns, R. dan Heber, D. (2009). California hass avocado: profiling of carotenoids, tocopherol, faty acid, and fat content during maturation dan from different growing area. Journal Agriculture and Food Chemistry 57(21): 10408-10413.

Rismundanar (1981). Memperbaiki Lingkungan dengan Bercocok Tanam Jambu Mede dan Alpukat. Sinar Baru, Bandung. 
Rodrigues-Carpena, Morcuende, D., Danrade, M.J., Killy, P. dan Estevez, W. (2011). Avocado (Persea americana Mill) phenolics, in vitro antioxidant, antimicrobial activities, and inhibition of lipid, protein oxidation in porcine patties. Journal of Agricultural and Food Chemistry 59: 5625-5635.

Schwartz, M., Olaeta, J., Undurraga, P. dan Costa, P. (2007). Major rendement of avocado cultivars. Proceeding of the VII World Avocado Congress, Vila Del Mar, Chile.

Sultana, B., Farooq, A. dan Przybylski, R. (2007). Antioxidant phenolic component present in bark of Azadirachta
indica,Terminalia arjuna,Acacia nilotica and Egugenia jambolana Lam. trees. Food Chemistry 104: 1106-1114.

Wang, W., Bostic, T.R. dan Gu, L. (2010). Antioxidant activity, procyanidins dan pigments in avocado of different strain dan cultivars. Food Chemistry 122: 1393-1398.

Zhou, K. dan Yu, L. (2004). Effect of extraction solvent in wheat bran antioxidant activity estimation. $L W T$ - Food Science and Technology 37: 717-721. 